\title{
FORM OF CODE MIX IN INDONESIAN LANGUAGE LEARNING STUDENTS GRADE VIII SMP NEGERI 1 AMBON
}

\author{
(Novita Tabelessy and Nancy Umkeketony)
}

\author{
noviariel.NF@gmail.com
}

\begin{abstract}
Code mixing is a form of using other languages besides code over. According to Nababan (in Suandi, 2014:139) that code mixing is the mixing of two or more languages or different languages in a speech act or discourse without anything in the language situation that demands mixing the language. Code mixing occurs when a speaker using a language predominantly supports a speech inserted with other language elements. It is usually related to the characteristics of the speaker, such as social background, level of education, religious sense. The object of research is a form of code mixing that occurs in the interaction of online learning of Indonesian subjects. The study used is Sociolinguistic. This type of research is qualitative by using interview techniques, field recording, and direct observation on the form of code mixing in online learning interactions of Indonesian subjects involving subject teachers and grade VIII students of SMP Negeri 1 Ambon. The results of the study found there were 19 forms of code mixing in the interaction of Indonesian language learning students in grade VIII SMP Negeri 1 Ambon. Data in the field shows, too, that not only do students produce code mixes in interactions, but teachers also produce fragments of code mix in communicating. Code mixing that occurs unconsciously is generated more by students, than subject teachers.
\end{abstract}

Keywords: Interaction, Learning, Teacher, Student, Code mix, Communication, Language

\section{Introduction}

Sociolinguistics is an interdisciplinary science between sociology and linguistics, two empirical fields of science that are very closely related. As an object in sociolinguistics, language is not seen or approached as a language, as is done by general linguistics, but rather is seen or approached as a means of interaction or communique in society. Sociolinguistics are commonly defined as sciences that study the characteristics and variety of languages, as well as the relationships among language society (Kridalaksana 1978:94). First of all sociolinguistic knowledge we can utilize in communicating or interacting. Sociolinguistics will guide us in communicating by showing what language, variety, or style of language we should use if we are talking to a particular person. If we are children in a family, of course we must use a different variety / style of language if our interlocut is father, mother, brother, or sister.

The term bilingualism in Indonesian is also called bilingualism. From the term literally can be understood what is meant by bilingualism, namely pleased 
with the use of two languages or two language codes. Sociolinguistically, in general, bilingulism is defined as a bilingual user by a speaker in his or her association with others interchangeably (Mackey 1962:12, Fisham 1975:73). Generally, bilingualism arises from a meeting between two or more groups of speakers of different languages. Contact between the two continuously produces people who can produce more than one language. In increasingly difficult associations the languages of the world survive on their own without any outside influence. Talking about code mix is usually followed by talk of code mixing. These two common events in bilingual society have great similarities, so they are often difficult to distinguish. Unlike code experts, code mixing does not appear because of the speech of the situation, but there are other things behind the occurrence of the code mix, Suwito (1983) suggested that there are three reasons for the code mix, among others:

1. Identify roles

2. Identification of variety

3. Desire to explain and interpret

The three reasons stated by the suwito are intertwined and do not often overlap. Measures for role identification are social, registral, and educational. Code mixing occurs to identify the role of speakers, both socially, regionally, and registerally.

Language selection is not an easy thing in a speech event. A person who is bilingual will of course think to choose what language he or she will use when speaking to others in a communication event. Kridalaksana (in Suandi, 2014:139) provides limits on code mix or interference as the use of language units from one language to another to expand the language style or variety of languages; including the use of words, clauses, idioms, greetings, and so on. Code mixing occurs when a speaker using a language predominantly supports a speech inserted with other language elements. It is usually related to the characteristics of the speaker, such as social background, level of education, religious sense.

This modern era, the level of student development is very rapid, they are easy to accept even master a foreign language, and often apply in conversation, both between students, students with teachers. In addition to foreign languages, regional languages (Ambon Malay Language) or accents are also often inserted in the conversations of students or teachers during the learning and learning process, this is what is called code mixing that occurs. The problem of code mixing in learning also occurs in students of SMP Negeri 1 Ambon. Even language mixing often occurs not only outside of learning hours, but often also in the learning process in the classroom. Given the current condition caused by the covid 19 pandemic, the learning process (teaching and learning activities) continues, even online.

This habit spurred researchers to want to know more about code mixing in the online learning interactions of Indonesian language subjects of grade VIII students of SMP Negeri 1 Ambon, and the factors that cause code mixing in the online learning process in each student's home. This habit must be eliminated, and students should be accustomed to using good and correct 
Indonesian language in the learning and learning process in the classroom (when conditions return to normal and school activities resume), that is one of the teacher's tasks that must be considered. Considering, the learning and learning process in the classroom is in the official realm.

\section{Research Methods}

This research is a quality descriptive research that is collected data in the form of words, images, and not numbers.

Data Collection Techniques

Researchers used several techniques for data collection at the research site of SMP Negeri 1 Ambon, data collection techniques in the form of:

\section{Observation}

Observations were made by researchers to obtain data and see firsthand the learning process occurred in which there is a mix of language codes between teachers and students, as well as students and students.

\section{Interviews}

The interviews conducted in this study were structured interviews, meaning that before going down to the school where the study was conducted, researchers had compiled a number of questions to ask teachers and students.

\section{Field Notes}

\section{Data and Data Sources}

This research data is in the form of words, phrases, clauses, sentences and repetitions containing code mixes that occur in the intercation of Indonesian language learning. The data source of this research is a grade VIII student at SMP Negeri 1 Ambon and one of the teachers of Bahasa Indonesia.

\section{Results and Discussion}

Research conducted for two months at SMP Negeri 1 Ambon, especially for grade VIII students, researchers found a form of code mixing in the interaction of Indonesian language learning as many as Nineteen forms of code mixing.

The mixed form of code that researchers found in the field there are several forms, consisting of words, phrases, clauses, sentences fund repetition. The form of code mix found there are Nineteen forms and can be seen in the table below:

\begin{tabular}{|c|c|c|c|c|c|c|c|}
\hline No & Data & Bahasa & \multicolumn{5}{|c|}{ Code Mix Form } \\
\cline { 5 - 8 } & & Indonesia & Words & Phrases & Clauses & Sentences & $\begin{array}{c}\text { Repete } \\
\text { tion }\end{array}$ \\
\hline 1 & Tado & Diam & $\sqrt{ }$ & & & & \\
\hline
\end{tabular}




\begin{tabular}{|c|c|c|c|c|c|c|c|}
\hline 2 & Tarima & Terima & $\sqrt{ }$ & & & & \\
\hline 3 & Sатиа & Semua & $\sqrt{ }$ & & & & \\
\hline 4 & Katong & Kami & $\sqrt{ }$ & & & & \\
\hline 5 & Ose & Kamu & $\sqrt{ }$ & & & & \\
\hline 6 & Beta & Saya & $\sqrt{ }$ & & & & \\
\hline 7 & Sapa & Siapa & $\sqrt{ }$ & & & & \\
\hline 8 & $O k$ & Oke & $\sqrt{ }$ & & & & \\
\hline 9 & Yes & Iya & $\sqrt{ }$ & & & & \\
\hline 10 & Ada saki & Lagi sakit & & $\sqrt{ }$ & & & \\
\hline 11 & $\begin{array}{l}\text { Baribot } \\
\text { lawing }\end{array}$ & $\begin{array}{l}\text { Ribut } \\
\text { sekali }\end{array}$ & & $\sqrt{ }$ & & & \\
\hline 12 & $\begin{array}{l}\text { Kamong } \\
\text { lia ka } \\
\text { buku }\end{array}$ & $\begin{array}{l}\text { Kalian } \\
\text { lihat ke } \\
\text { buku }\end{array}$ & & & $\sqrt{ }$ & & \\
\hline 13 & $\begin{array}{l}\text { Sapa yang } \\
\text { su biking } \\
\text { tugas }\end{array}$ & $\begin{array}{l}\text { Siapa } \\
\text { yang } \\
\text { sudah } \\
\text { membuat } \\
\text { tugas }\end{array}$ & & & & $\sqrt{ }$ & \\
\hline 14 & $\begin{array}{l}\text { Io e dong } \\
\text { baribot } \\
\text { lawing }\end{array}$ & $\begin{array}{ll}\text { Iya } & \text { ya, } \\
\text { kalian } & \\
\text { ribut } & \\
\text { sekali } & \end{array}$ & & & & $\sqrt{ }$ & \\
\hline 15 & $\begin{array}{l}\text { Beta seng } \\
\text { dengar } \\
\text { Mira } \\
\text { bilang } \\
\text { apa }\end{array}$ & $\begin{array}{l}\text { Saya tidak } \\
\text { mendenga } \\
\mathrm{r} \text { apa yang } \\
\text { Mira } \\
\text { katakan }\end{array}$ & & & & $\sqrt{ }$ & \\
\hline 16 & Inga-inga & $\begin{array}{l}\text { Ingat- } \\
\text { ingat }\end{array}$ & & & & & $\sqrt{ }$ \\
\hline 17 & Tado-tado & $\begin{array}{l}\text { Diam- } \\
\text { diam }\end{array}$ & & & & & $\sqrt{ }$ \\
\hline 18 & $\begin{array}{l}\text { Ulang- } \\
\text { ulang }\end{array}$ & $\begin{array}{l}\text { Mengulan } \\
\text { g }\end{array}$ & & & & & $\sqrt{ }$ \\
\hline 19 & Bae-bae & Baik-baik & & & & & $\sqrt{ }$ \\
\hline
\end{tabular}

The form of code mixing in detail can be discussed below, but not all the data listed in the table is analyzed by researchers, the following are only some of the data analyzed.

\section{a. Words}

According to KBBI (2016) the word is an element of language spoken or written that is the manifestation of the unity of feelings and thoughts that can be used in language. The word is also the largest unit in morphology and is considered the smallest unit in syntax. Here's data that shows code mix events in the form of words.

\section{Data 01}


Teacher : Tolong kalian tadoh dan siap tarima materi yang akan Ibu berikan

hari ini

(Kalian diharapkan tenang dan siap menerima materi yang akan diberikan Ibu hari ini)

Students : baik Ibu. Samua diharapkan tenang.

(Baik Ibu. Semua diharapkan tenang)

The teacher started the lesson using the official variety of Indonesian language, but the teacher did not realize that in his speech it had mixed code between Indonesian and Ambon Malay language. The response from the students was so, there was a code mix but the student was not aware of it. In the teacher's speech (data 01) there are fragments of the Malay word Ambon "tadoh" and "tarima" which means "calm" and "accept" and the fragment of the Malay word Ambon "samua" which means "all". Mix the code in the form of fragments of the Word Melayu Ambon to ask about the readiness of students in receiving lessons that begin immediately. The occurrence of code mixing between teachers and students from Indonesian to Ambon Malay language when in the learning process is unconsciously.

Data 02

Teacher : Ketua kelas, hari ini ada yang tidak hadir ?

Students : Katong semua hadir, Ibu.

(Kami semua hadir, Ibu)

Before starting the lesson, the teacher asks and checks the attendance of the students who are present and not present. The response from the students was that there was a fragment of the Malay word Ambon "katong" which means "we". Mix the code in the form of fragments of the Word Malay Ambon to respond to the teacher's questions about the presence of students.

\section{b. Phrases}

According to KBBI (2016) the phrase is a combination of two or more words that are nonpredication. The definition of a phrase in general is a combination of nonpredication words, consisting of two words. The phrase is nonpredication which means that one of the words contained in the combination of words does not serve as a predicate. Here's the data that shows code mix events in the form of phrases.

Data 05

Teacher : Maria mana ya ? tiba-tiba kameranya mati

Students : Ibu guru, Maria ada saki, Maria baru saja sms saya, Ibu (Ibu guru, Maria sedang sakit)

Student speech is a form of code mix in the form of phrases, students do not realize that what he is saying is Ambon malay language that should not be claimed, because they are still in the learning process. Mix the code in the form of the phrase "ada saki" meaning "being sick". Mixing codes in the form of phrases that students do is to inform the teacher about his friend who is sick.

c. Clauses

Clauses are grammatical units in the form of word groups, consisting of at least subjects and predicates and potentially sentences. Here's data showing code mix events in the form of clauses.Data 07

Teacher : Kamong lia ka buku

(Kalian lihat ke buku)

Students : Baik, Ibu guru 
The teacher told the students to look at and read the material in the package book, but the teacher did not realize that the speech had been mixed with ambon malay language, no longer using the official variety language. The student's response to the teacher's speech was that the student answered using the official language, Bahasa Indonesia. In the teacher's speech on Data 07 there is a fragment of code mix in the form of clause "kamong lia ka buku" meaning "you see (read) into the package book". The fragments of the malay language code are spoken by the teacher with the aim of reprimanding and reminding students to focus on the material being taught in the package book. The occurrence of code interference from the teacher's speech unconsciously.

\section{d. Sentences}

\section{Data 09}

Student 1 : Beta seng ulang lai (Saya tidak mengulang lagi)

Student 2 : Io e, dong baribot lawang, beta seng dengar Mira bilang apa (Iya ya, mereka sangat ribut, saya tidak mendengar apa yang Mira katakan)

The teacher told the students to look at and read the material in the package book, but the teacher did not realize that the speech had been mixed with ambon malay language, no longer using the official variety language. The student's response to the teacher's speech was that the student answered using the official language, Bahasa Indonesia. In the teacher's speech on Data 07 there is a fragment of code mix in the form of clause "kamong lia ka buku" meaning "you see (read) into the package book". The fragments of the malay language code are spoken by the teacher with the aim of reprimanding and reminding students to focus on the material being taught in the package book. The occurrence of code interference from the teacher's speech unconsciously.Mira.

\section{e. Repetition}

Student 1 : Saya sudah lupa ada tugas Bahasa Indonesia

Student 2 : Inga-inga jua tamang

(Ingat-ingat dulu teman)

The event of code mix in data 10 is a mix of Ambon malay language code in the form of repetition. The speech of student 1 uses Indonesian language, but the response from student 2 is unwittingly said that the mix of Ambon Malay language code is in the form of repetition, namely "inga-inga" which means "remember". The use of code mix in the speech of student 1 with the aim to remind his friend who forgot to do Indonesian language assignments. Such is the exposure of data and discussion clearly about the data found by researchers at SMP Negeri 1 Ambon in teachers and students in grade VIII. Overall, the results of the study on code mixing were researchers found three factors that caused code mixing in students and teachers in the form of habitual factors, factors in terms of speakers, and influence factors of the first language, in addition researchers also found there were 12 code mix data found in the form of words, phrases, clauses, sentences, and repetitions. 


\section{Conclusion}

Based on the results and discussions that have been presented above, the conclusion is found there are several forms of code mixing that occur in the interaction of Indonesian language learning between teachers and students, namely the form of code mix in the form of words ( 9 pieces), phrases ( 2 pieces), clauses ( 1 piece), sentences ( 3 pieces), and repetition (4 pieces). Code mixing that occurs in the interaction of Indonesian language learning is more dominant produced by students than teachers.

\section{References}

Chair Abdul, Agustina Leonie. 2014. Sosiolinguistik Perkenalan Awal. Jakarta. Reka Cipta.

Kamus Besar Bahasa Indonesia. 2016

Moleong, Lexy. 2017. Metodologi Penelitian Kualitatif. Bandung: Rosda

Suandi Nengah I. 2014. Sosiolinguistik. Yogyakarta. Graha Ilmu.

Sugiyono, 2014. Metodologi Penelitian; Kuantitatif, Kualitatif, $R \& D$. Bandung: Alfabetha.

Widya Dewa da Rohmadi. 2012. Sosiolinguistik Kajian Teori dan Analisis. Yogyakarta: Pustaka Pelajar. 